\title{
4-Nonylphenol induces immunomodulation and apoptotic events in the clam Tapes philippinarum
}

\author{
Valerio Matozzo, Maria Gabriella Marin* \\ Department of Biology, University of Padova, Via Ugo Bassi 58/B, 35131 Padova, Italy
}

\begin{abstract}
The effects of 4-nonylphenol (NP) on functional responses of haemocytes from the clam Tapes philippinarum were investigated after $7 \mathrm{~d}$ exposure to sublethal NP concentrations $(0,0+$ acetone, $0.025,0.05,0.1$ and $0.2 \mathrm{mg} \mathrm{l}^{-1} \mathrm{NP}$ ). Haemocytes from both controls and exposed clams were collected, and the effects of NP on uptake of the vital dye Neutral Red (NR), superoxide dismutase (SOD) and lysozyme activities, total haemocyte count (THC) and volume of circulating cells were evaluated. The capability of NP to induce apoptosis was also investigated. Exposure of clams to $0.2 \mathrm{mg} \mathrm{l}^{-1} \mathrm{NP}$ significantly increased $(p<0.05)$ NR uptake when compared with controls, suggesting that NP caused alterations in cell membrane stability. Significant decreases in both SOD and lysozyme activity were observed from $0.05 \mathrm{mg} \mathrm{l}^{-1} \mathrm{NP}(\mathrm{p}<0.01$ and $\mathrm{p}<0.05$, respectively) with respect to controls, indicating that NP causes oxidative stress and reduces the immunocompetence of the exposed clams. From $0.05 \mathrm{mg} \mathrm{l}^{-1} \mathrm{NP}$, the apoptotic index (percentage of haemocytes showing positivity to the TUNEL reaction) significantly increased $(p<0.001)$. Apoptotic haemocytes showed shrinkage and lost their amoeboid shape. Moreover, NP exposure significantly increased THC ( $p<0.05$ at $0.2 \mathrm{mg} \mathrm{l}^{-1} \mathrm{NP}$ ) and caused a different distribution in size frequency. On the basis of the threshold concentration values, the most sensitive endpoints for NP were SOD, lysozyme and apoptosis assays. Our results highlight a relationship between NP exposure and changes in the functional responses of haemocytes, suggesting that the contaminant induces immunomodulation in $T$. philippinarum, mainly by altering cell morphology, cell membrane stability and enzymatic activities, and by promoting oxidative stress and apoptotic events.
\end{abstract}

KEY WORDS: Nonylphenol $\cdot$ Xenoestrogens $\cdot$ Bivalves $\cdot$ Haemocytes $\cdot$ Immunotoxicity $\cdot$ Apoptosis $\cdot$ Cell volume Resale or republication not permitted without written consent of the publisher

\section{INTRODUCTION}

Numerous studies have demonstrated that contaminants can induce immunomodulation in bivalve molluscs by altering the functional responses of haemocytes, circulating cells known to play an important role in the internal defence of these animals. Alterations in immunocompetence have been reported for bivalves after exposure, both in vitro and in vivo, to organic and inorganic contaminants, such as heavy metals (Cheng \& Sullivan 1984, Cheng 1988, Viarengo et al. 1994, Coles et al. 1995, Pipe et al. 1999, Matozzo et al. 2001, Sauvé et al. 2002), organotins (Fisher et al. 1990, Auffret \& Oubella 1997, Cima et al. 1998, Matozzo et al. 2002), fungicides (Alvarez \& Friedl 1992), polycyclic aromatic hydrocarbons (PAHs) (Sami et al. 1992, Coles et al. 1994, Grundy et al. 1996, Gómez-Mendikute et al. 2002) and chlorinated phenols (Florence et al. 1997). Among the functional responses of bivalve circulating cells, total haemocyte count (THC), viability, motility, aggregation and adhesion capability, phagocytosis, production of reactive oxygen species (ROS), hydrolytic and oxidative enzyme activities, and lysosomal and cell membrane stability are all generally recognised as useful biomarkers in immunotoxicity studies.

At the present time, limited data are available on nonylphenol (NP)-mediated immunomodulation in bivalves. NP is used in the production of nonylphenol ethoxylates (NPEs), NP phosphites and insecticide 
sprays (Maguire 1999). NP phosphites are used as stabilisers and antioxidant agents in both rubber and plastic industries, and NPEs are nonionic surfactants commonly employed in plastics, latex paints, lubricating oils, emulsifiers, household and industrial detergents, and paper and textile industries (Lee 1999). As a consequence of their widespread use, NPEs are discharged in large quantities into aquatic environments, either directly from untreated effluents or indirectly from sewage treatment plants (STPs) (Ekelund et al. 1993, Maguire 1999). NPEs are not persistent in aquatic ecosystems but biodegrade to de-ethoxylated intermediates, of which NP is the final product (Maguire 1999). In water and sediment, NP appears to be more persistent to degradation than NPEs (Brunner et al. 1988, Ekelund et al. 1993), and, owing to its higher lipophilicity, can be accumulated by aquatic organisms (Ekelund et al. 1990, Ahel et al. 1993). The adverse effects of both NP and NPEs have been reported in fish and aquatic invertebrates, although NP appears to be acutely toxic at lower concentrations with respect to NPEs, their toxicity reducing with decreasing ethoxylate unit chain lengths (Servos 1999). It has been shown that NP affects population growth rates in invertebrates, as observed in the infaunal polychaete Capitella sp. and the marine copepod Tisbe battagliai (Bechmann 1999, Hansen et al. 1999). Moreover, NP reduced the scope for growth in the Manila clam Tapes philippinarum (Matozzo et al. 2003a) and the mussel Mytilus edulis (Granmo et al. 1989). NP and NPEs also alter hormonal functions in various aquatic organisms, being able to mimic the action of endogenous estrogens, such as $17 \beta$-estradiol $\left(E_{2}\right)$, by binding estrogen receptors (Arukwe et al. 1997, Madigou et al. 2001). As a consequence, these estrogenic compounds induce vitellogenin synthesis (vitellogenins are the major precursor of the egg-yolk proteins in oviparous females) in exposed males (Christiansen et al. 1998, Christensen et al. 1999). Indeed, as the vitellogenin gene (normally silent) is also present in males, it may be activated by (xeno-) estrogens (Flouriot et al. 1995).

Since data about the immunotoxicity of NP in bivalves are lacking, the present study was addressed to assess NP's effects on the functional responses of haemocytes from a widespread and economically relevant clam species in the Lagoon of Venice (Italy). In water samples from various stations of the Lagoon, the mean concentration values of NPEs, including NP, peak at $39 \mu \mathrm{l} \mathrm{l}^{-1}$ (Marcomini et al. 2000). Similarly, in estuarine areas of Croatia and England, NP levels as high as 2.3 and $5.2 \mu \mathrm{g} \mathrm{l}^{-1}$, respectively, have been detected (Kvestak \& Ahel 1994, Blackburn \& Waldock 1995). A number of other reports reviewed by Ying et al. (2002) indicate NP levels ranging from the limit of detection to $644 \mu \mathrm{g} \mathrm{l}^{-1}$ in surface waters around the world. However, NP levels in the sediments are much higher than in the corresponding surface waters, thus representing an important source for future contamination (Bennie 1999, Ying et al. 2002).

In this study, specimens of Tapes philippinarum were exposed to sublethal and environmentally realistic NP concentrations to evaluate the effects on uptake of the vital dye Neutral Red (NR) (as an index of cell membrane stability), activity of superoxide dismutase (SOD, antioxidant enzyme) and lysozyme (bacteriolytic enzyme), THC, and the volume of circulating cells. The capability of NP to induce apoptotic events in haemocytes from NP-exposed clams was also investigated.

\section{MATERIALS AND METHODS}

Animals. Specimens of Tapes philippinarum were collected from a reference site located inside a licensed area for clam culture in the southern basin of the Lagoon of Venice (Italy) and acclimatised in the laboratory for $7 \mathrm{~d}$ before exposure to NP. The clams were kept in large aquaria provided with a sandy bottom and aerated sea water (salinity of $35 \pm 1 \%$, temperature of $17 \pm 0.5^{\circ} \mathrm{C}$ ) and fed with the microalgae Isochrysis galbana.

4-Nonylphenol solutions. NP, a mixture of p-isomers, was purchased from Fluka Chemika. Owing to its low solubility in water, a stock solution of NP was prepared in acetone and stored at room temperature for the duration of the experiments. Working solutions were prepared daily by diluting the stock solution in sea water.

Exposure to NP. To evaluate NP effects on functional responses of haemocytes, 2 series of experiments were performed. In the former, 15 animals per concentration were exposed for $7 \mathrm{~d}$ to $0,0+$ acetone, $0.025,0.05,0.1$ and $0.2 \mathrm{mg} \mathrm{l}^{-1} \mathrm{NP}$ to evaluate NP effects on NR uptake, SOD and lysozyme activities, and apoptosis. In the latter, 20 clams per concentration were exposed to the same NP concentrations to study the effects on both THC and volume of circulating haemocytes. The nominal exposure concentrations were chosen on the basis of the $\mathrm{LC}_{50}$ value (1.12 $\mathrm{mg} \mathrm{NP}^{-1}$ ) recorded in Tapes philippinarum (Matozzo et al. 2003a). In acetone controls, solvent was added at the highest concentration $\left(16 \mu \mathrm{l} \mathrm{l}^{-1}\right)$ used in NP treatments. Clams were maintained in glass aquaria (without sediment) containing aerated sea water (1 1 per animal), in the same thermohaline conditions used in the acclimatisation period. Water was changed every day, and NP and microalgae added (Isochrysis galbana, at an initial concentration of about 100000 cells $\mathrm{l}^{-1}$ ). 
Haemolymph collection. After NP exposure, haemolymph was collected from the anterior adductor muscle in a $1 \mathrm{ml}$ plastic syringe and placed in Eppendorf tubes at $4^{\circ} \mathrm{C}$. In the first series of experiments, 3 pools of haemolymph obtained from control and NP-exposed clams (5 animals per pool) were used, in the second series, 4 pools of haemolymph (5 animals per pool) were used.

NR uptake assay. The cationic probe, NR (Merck), was used to evaluate haemocyte membrane stability after NP exposure. Alterations in its uptake are commonly recognised as an indicator of cell damage in in vitro studies (Gómez-Mendikute et al. 2002, Matozzo et al. 2002). Haemolymph (final volume $=1 \mathrm{ml}$ ) from both NP-treated and untreated clams (controls) was centrifuged at $780 \times g$ for $10 \mathrm{~min}$, haemocytes were resuspended in an equal volume of $8 \mathrm{mg} \mathrm{l}^{-1} \mathrm{NR}$ dye solution in filtered seawater (FSW) and then incubated at $25^{\circ} \mathrm{C}$ for $30 \mathrm{~min}$. They were then centrifuged at $780 \times$ $g$ for $10 \mathrm{~min}$, resuspended in distilled water, sonicated at $0^{\circ} \mathrm{C}$ for 1 min with a Braun Labsonic $\mathrm{U}$ sonifier at $50 \%$ duty cycles, and centrifuged at $12000 \times g$ for $15 \mathrm{~min}$ at $4^{\circ} \mathrm{C}$. Supernatant, corresponding to cell lysate (CL), was collected for the NR uptake assay. CL $(200 \mu \mathrm{l})$ was put in the wells of a 96-well microplate and absorbance at $550 \mathrm{~nm}$ was recorded with a microplate reader (Reader SR400, Techno Genetics). Results were expressed as optical density per mg protein (OD mg protein ${ }^{-1}$ ). CL protein concentrations were quantified according to Bradford (1976) using bovine serum albumin (BSA) as standard.

SOD activity assay. SOD activity was measured according to the method of Flohé \& Ötting (1984), based on the reduction of cytochrome $c$ by the superoxide radical $\left(\mathrm{O}_{2}{ }^{-}\right)$. Haemolymph from exposed and unexposed clams was centrifuged at $780 \times g$ for $10 \mathrm{~min}$, resuspended in distilled water, sonicated and centrifuged as described above. CL was collected and used for the SOD activity assay. CL (50 $\mu$ l) was added to $900 \mu \mathrm{l}$ of solution A ( $5 \mu \mathrm{M}$ xanthine [Sigma] in $1 \mathrm{mM}$ $\mathrm{NaOH}, 2 \mu \mathrm{M}$ cytochrome $c$ [Sigma] and $0.1 \mathrm{mM}$ EDTA in $50 \mathrm{mM}$ phosphate buffer, $\mathrm{pH} 7.8$ [2.72 $\mathrm{g} \mathrm{l}^{-1} \mathrm{KH}_{2} \mathrm{PO}_{4}$ and $5.34 \mathrm{~g} \mathrm{l}^{-1} \quad \mathrm{Na}_{2} \mathrm{HPO}_{4} \cdot 2 \mathrm{H}_{2} \mathrm{O}$ in distilled water]) and to $50 \mu \mathrm{l}$ of solution $\mathrm{B}(0.45 \mathrm{U}$ xanthine oxidase [Sigma], $1 \mathrm{ml} 0.1 \mathrm{mM}$ EDTA in $50 \mathrm{mM}$ phosphate buffer, $\mathrm{pH}$ 7.8). Changes in absorbance at $550 \mathrm{~nm}$ were continuously recorded for 2 min with a Uvikon 930 spectrophotometer. Results were expressed as U SOD mg protein ${ }^{-1}$. According to Flohé \& Ötting (1984), 1 unit of SOD is defined as the amount of enzyme inhibiting the reduction of cytochrome $c$ by $50 \%$.

Lysozyme activity assay. Lysozyme activity was quantified according to Santarem et al. (1994). CL $(50 \mu \mathrm{l})$, obtained as described above, was added to $950 \mu \mathrm{l}$ of a $0.15 \%$ suspension of Micrococcus lysodeik- ticus (Sigma) in $66 \mathrm{mM}$ phosphate buffer, $\mathrm{pH}$ 6.2, and the decrease in absorbance $\left(\Delta \mathrm{A} \mathrm{min}^{-1}\right)$ was continuously recorded at $450 \mathrm{~nm}$ for $5 \mathrm{~min}$ at $20^{\circ} \mathrm{C}$. Standard solutions containing 1, 2.5, 5 and $10 \mu \mathrm{g}$ lysozyme per $\mathrm{ml}$ of $66 \mathrm{mM}$ phosphate buffer, $\mathrm{pH}$ 6.2, were prepared from crystalline hen egg white lysozyme (Sigma). The average decrease in absorbance per minute was determined for each enzyme solution and a standard curve of enzyme concentration versus $\Delta \mathrm{A} \mathrm{min}^{-1}$ was drawn. A unit of lysozyme was defined as the amount of enzyme producing an activity equivalent to $1 \mu \mathrm{g}$ of lysozyme, in the conditions described above. Results were expressed as $\mu \mathrm{g}$ lysozyme mg protein ${ }^{-1}$.

Short-term haemocyte cultures and apoptosis assay. DNA fragmentation, a biochemical feature of apoptosis, was investigated in cultured haemocytes using the TUNEL reaction mixture (In Situ Cell Death Detection Kit, Boehringer Mannheim). After NP exposure, haemolymph from both controls and NP-exposed clams was collected in a $1 \mathrm{ml}$ plastic syringe containing $300 \mu \mathrm{l}$ of $10 \mathrm{mM}$ L-cysteine in FSW, pH 7.5, to prevent clotting, and centrifuged at $780 \times g$ for $10 \mathrm{~min}$. Haemocytes were then resuspended in FSW at a final concentration of $10^{6}$ cells $\mathrm{ml}^{-1}$ to prepare short-term haemocyte cultures, according to Ballarin et al. (1994). Haemocyte suspensions $(60 \mu \mathrm{l})$ were placed in the centre of culture chambers made by a teflon ring (15 mm internal diameter and $1 \mathrm{~mm}$ thick), smeared with vaseline, glued to a siliconised glass slide and covered with a coverslip. Chambers were kept upside down for $30 \mathrm{~min}$ at $25^{\circ} \mathrm{C}$ to allow haemocytes to settle and adhere to coverslips. After adhesion to coverslips, haemocytes were fixed in a $4 \%$ paraformaldehyde solution in ISO buffer (Tris $20 \mathrm{mM}, \mathrm{NaCl} 0.5 \mathrm{M}, \mathrm{pH} 7.5$ ) for $30 \mathrm{~min}$ at $25^{\circ} \mathrm{C}$, rinsed with phosphate buffer (PBS: $1.37 \mathrm{M} \mathrm{NaCl}, 0.03 \mathrm{M} \mathrm{KCl}$, $0.015 \mathrm{M} \mathrm{KH}_{2} \mathrm{PO}_{4}, 0.065 \mathrm{M} \mathrm{Na}_{2} \mathrm{HPO}_{4}, \mathrm{pH}$ 7.2) and incubated for $2 \mathrm{~min}$ at $4^{\circ} \mathrm{C}$ in a permeabilisation solution containing $0.1 \%$ Triton X-100 (Merck) in $0.1 \%$ sodium citrate. Haemocytes were rinsed in PBS and then incubated in the TUNEL reaction mixture for $1 \mathrm{~h}$ at $37^{\circ} \mathrm{C}$. During this phase, the enzyme deoxynucleotidyl transferase (TdT) catalyses the attachment of fluorescein isothiocyanate-labelled dUTP to free 3 '-OH DNA ends. Haemocytes were then observed under a fluorescence microscope and the apoptotic index expressed as the percentage of haemocytes (at least 500 cells in 10 fields per slide were counted) showing positivity to the TUNEL reaction (apoptotic nuclei appeared greenishyellow).

THC and haemocyte volume determination. Both THC and haemocyte volume were measured by an electronic particle counter/size analyser (Coulter Counter, Model Z2). Pooled haemolymph (500 $\mu$ l) was added to $19.5 \mathrm{ml}$ of $0.45 \mu \mathrm{m}-\mathrm{FSW}$, and both total numbers and volume of circulating haemocytes were 
immediately estimated. THC and haemocyte volume results were expressed as number of haemocytes $\left(\times 10^{6}\right) \mathrm{ml}^{\text {haemolymph}}{ }^{-1}$ and femtolitre (fl), respectively.

Statistical analysis. For all indices, data were checked for normal distribution (Shapiro-Wilk's test) and homogeneity of variance (Bartlett's test). Results of NR uptake, lysozyme and SOD activity assays were compared using a 1-way ANOVA, followed by a post hoc test (Duncan's test). When ANOVA assumptions were not fulfilled (e.g. THC results), the non-parametric Mann-Whitney $U$-test was used to perform pairwise comparisons between treatments. The results of the apoptosis assay were compared by the $\chi^{2}$ test. All results were expressed as means $\pm \mathrm{SD}$. For all indices, threshold concentrations were evaluated as the geometric mean of the highest tested concentration that produced no statistically significant observable effect (NOEC) and the lowest tested concentration that produced a statistically significant observable adverse effect (LOEC). The software packages STATISTICA 5.5 (StatSoft) and SAS (SAS Institute) were used for statistical analyses.

\section{RESULTS}

Alterations were observed in all the cell parameters analysed. Indeed, exposure to $0.2 \mathrm{mg} \mathrm{l}^{-1} \mathrm{NP}$ resulted in significant increases $(\mathrm{p}<0.05)$ in NR uptake, when compared with controls (Fig. 1).

The effects of NP on enzyme activities are shown in Figs. $2 \& 3$, respectively. SOD significantly decreased from $0.05 \mathrm{mg} \mathrm{l}^{-1} \mathrm{NP}(\mathrm{p}<0.01)$, with respect to controls.

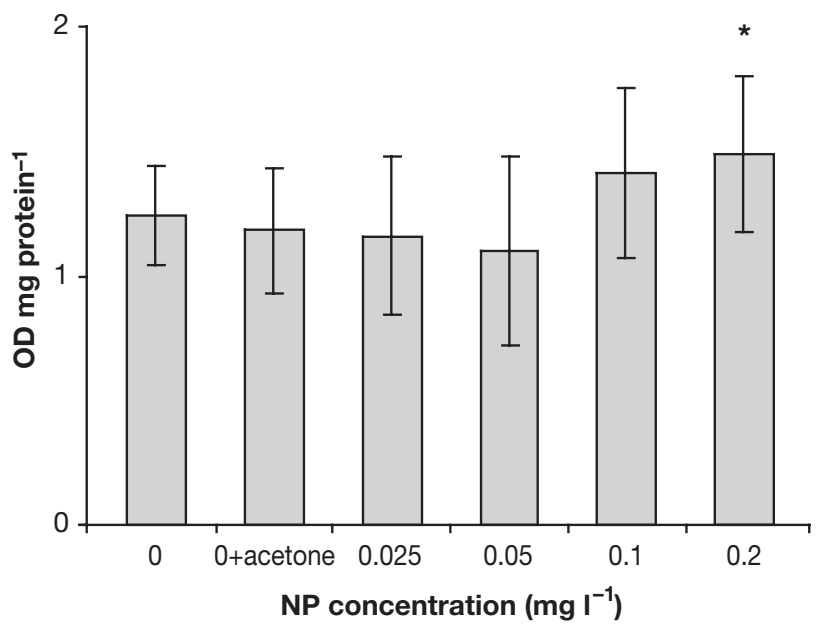

Fig. 1. Tapes philippinarum. Effects of NP on the capability of haemocytes to take up Neutral Red dye. Results are expressed as OD mg protein ${ }^{-1}$. Asterisks: significant results in comparison with controls. Values are means $\pm \mathrm{SD}_{i} \mathrm{n}=3 ;{ }^{*} \mathrm{p}<0.05$

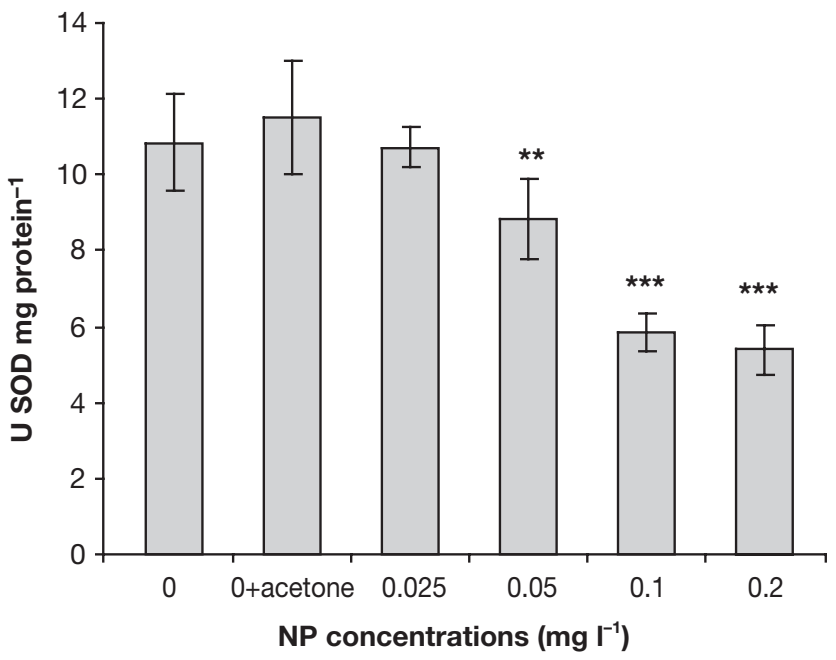

Fig. 2. Tapes philippinarum. Effects of NP on SOD activity, expressed as U SOD mg protein ${ }^{-1}$, in haemocytes. Asterisks: significant results in comparison with controls. Values are means $\pm \mathrm{SD}_{i} \mathrm{n}=3 ;{ }^{* *} \mathrm{p}<0.01, * * * \mathrm{p}<0.001$

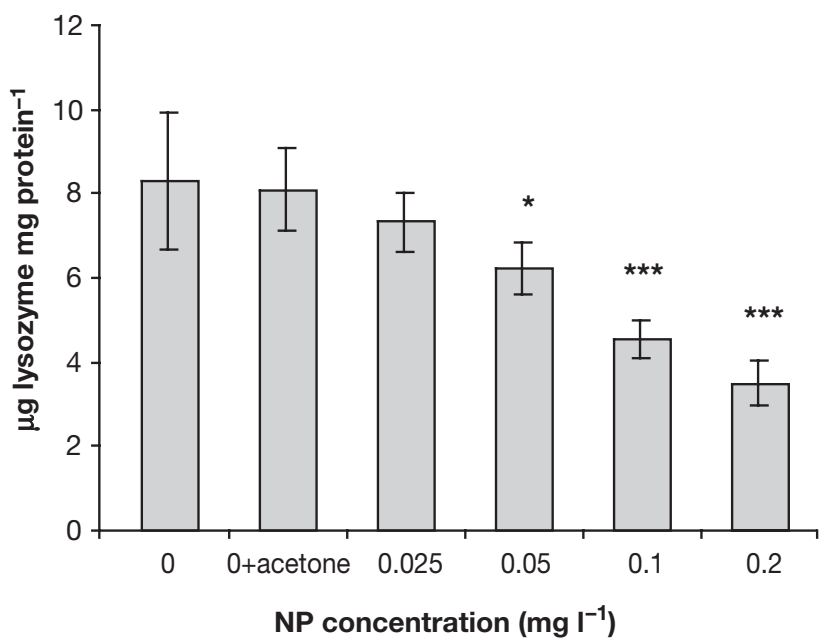

Fig. 3. Tapes philippinarum. Effects of NP on lysozyme activity, expressed as $\mu \mathrm{g}$ lysozyme mg protein ${ }^{-1}$, in haemocytes. Asterisks: significant results in comparison with controls.

Values are means $\pm \mathrm{SD} ; \mathrm{n}=3 ;{ }^{*} \mathrm{p}<0.05, * * * \mathrm{p}<0.001$

In $0.05 \mathrm{mg} \mathrm{l}^{-1} \mathrm{NP}$-exposed clams, SOD activity was also significantly lower when compared with that in $0.025 \mathrm{mg} \mathrm{l}^{-1} \mathrm{NP}$-exposed animals $(\mathrm{p}<0.05)$. Moreover, clams exposed to 0.1 and $0.2 \mathrm{mg} \mathrm{l}^{-1} \mathrm{NP}$ showed lower SOD activity $(\mathrm{p}<0.001)$ when compared with 0.025 and $0.05 \mathrm{mg} \mathrm{l}^{-1} \mathrm{NP}$-exposed clams. Lysozyme activity was significantly reduced $(p<0.05)$ in haemocytes from clams exposed to $0.05 \mathrm{mg} \mathrm{l}^{-1} \mathrm{NP}$, with respect to controls. At 0.1 and $0.2 \mathrm{mg} \mathrm{l}^{-1} \mathrm{NP}$, lysozyme activity significantly decreased when compared with $0.025 \mathrm{mg}$ $\mathrm{l}^{-1} \mathrm{NP}(\mathrm{p}<0.01$ and $\mathrm{p}<0.001$, respectively) and $0.05 \mathrm{mg} \mathrm{l}^{-1} \mathrm{NP}$-exposed animals $(\mathrm{p}<0.05$ and $\mathrm{p}<0.01$, respectively). 


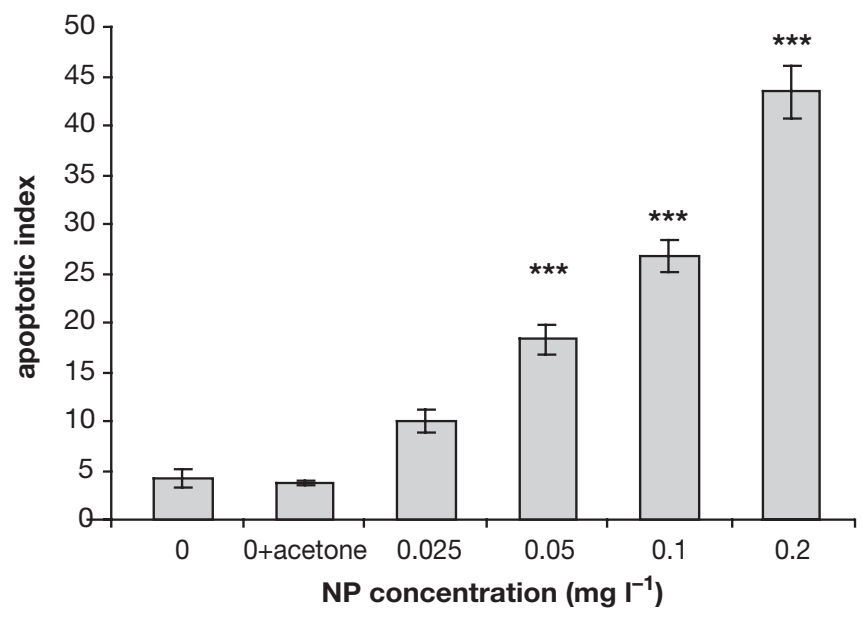

Fig. 4. Tapes philippinarum. Apoptotic index, expressed as percentage of haemocytes positive to TUNEL reaction after exposure to NP. Asterisks: significant results in comparison with controls. Values are means $\pm \mathrm{SD} ; \mathrm{n}=3_{i} * * * \mathrm{p}<0.001$

A significant increase $(p<0.001)$ in the apoptotic index was observed in haemocytes from bivalves exposed to $0.05 \mathrm{mg} \mathrm{l}^{-1} \mathrm{NP}$ (Fig. 4). Haemocytes from NP-exposed clams underwent a series of morphological changes: apoptotic haemocytes generally showed a marked decrease in cell volume and lost their characteristic amoeboid shape, as cells withdrew their pseudopodia (Fig. 5).

Exposure to NP also resulted in a dose-dependent different haemocyte size frequency distribution: the fractions of both smaller $(<100 \mathrm{fl})$ and larger haemocytes (>400 fl) appeared increased at the highest NP concentrations tested with respect to controls (Fig. 6). Moreover, at the end of NP exposure, a significant increase $(\mathrm{p}<0.05)$ in THC was recorded, ranging from a mean of $2.9 \times 10^{6}$ cells ml ${ }^{-1}$ in controls to $6.4 \times 10^{6}$ cells $\mathrm{ml}^{-1}$ in $0.2 \mathrm{mg} \mathrm{l}^{-1} \mathrm{NP}$-exposed clams (Fig. 7).

The threshold concentration was $0.14 \mathrm{mg} \mathrm{l}^{-1} \mathrm{NP}$ in NR uptake and THC assays, and $0.035 \mathrm{mg} \mathrm{l}^{-1} \mathrm{NP}$ in SOD, lysozyme and apoptosis assays.

\section{DISCUSSION}

As reported by various authors, bivalve haemocytes play a key role in internal defence against pathogens and foreign materials. Consequently, the adverse effects of contaminants on haemocyte functionality may increase the susceptibility of animals to diseases and reduce their survival capability. In the present study, marked alterations in the functional responses of haemocytes were observed after $7 \mathrm{~d}$ exposure of Tapes philippinarum to sublethal NP concentrations, indicating a decrease in their immunocompetence and, thus, highlighting a condition of potential risk for the well-being of clam populations in estuarine areas.

NR is commonly used in in vitro bioassays based on the accumulation of this cationic dye into the lysosomes of viable cells. Uptake by haemocytes generally occurs either by pinocytosis or passive diffusion across
Fig. 5. Tapes philippinarum. Haemocytes after exposure to NP. Phase-contrast micrographs: control haemocytes showing amoeboid shape (arrows) (a), and haemocytes from $0.2 \mathrm{mg} \mathrm{l}^{-1} \mathrm{NP}$-exposed clams showing spherical shape (arrows) (b). Fluorescence micrographs: haemocytes from $0.1 \mathrm{mg} \mathrm{l}^{-1}$ (c) and $0.2 \mathrm{mg} \mathrm{l}^{-1}$ (d) NP-exposed clams showing positivity to TUNEL reaction (apoptotic cells showed greenishyellow nuclei) and spherical shape (arrows). Scale bars $=3 \mu \mathrm{m}$
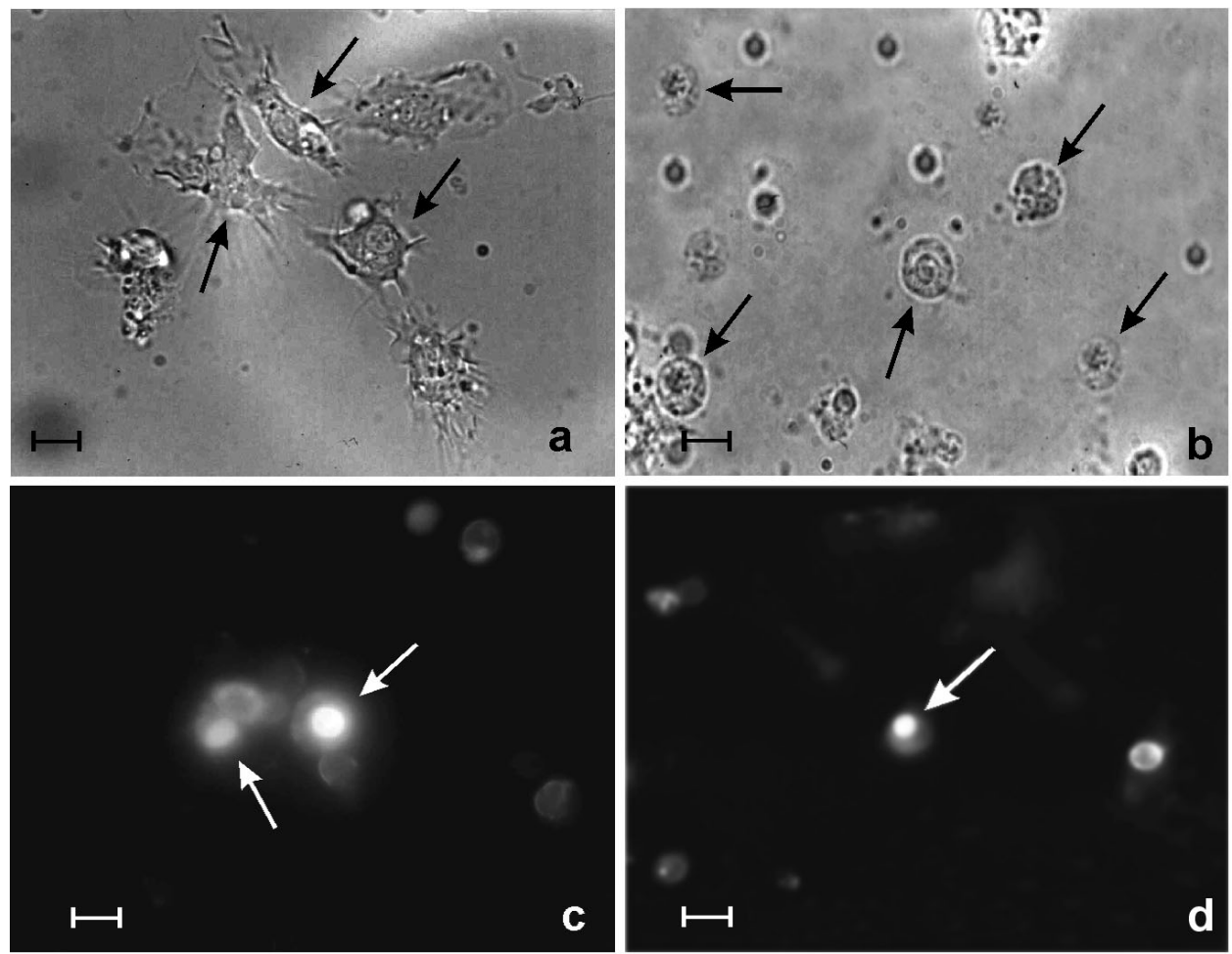

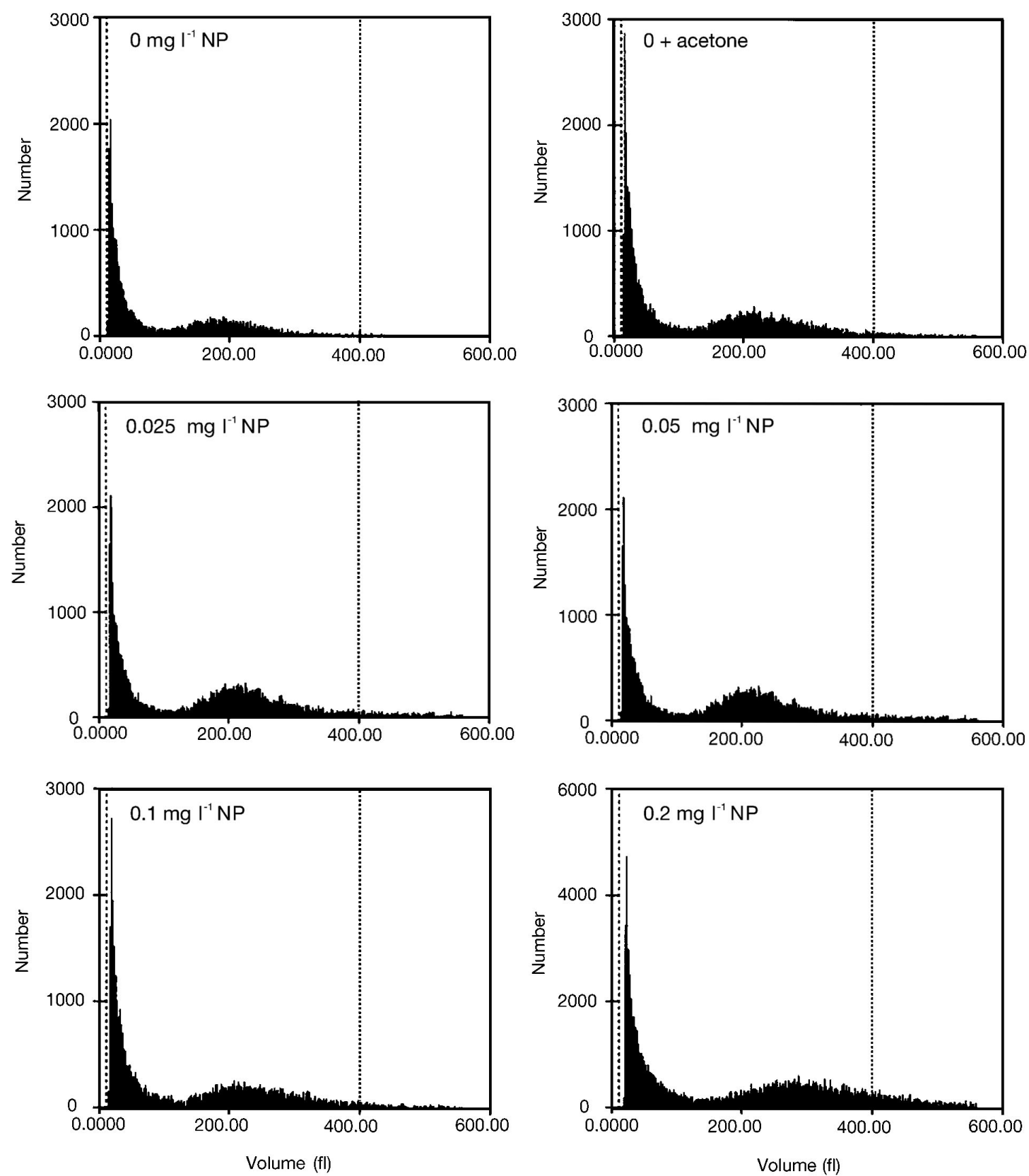

Fig. 6. Tapes philippinarum. Haemocyte size frequency distribution (volumes expressed as femtolitre) after exposure to NP

cell membranes (Coles et al. 1995). Alterations in dye uptake may, therefore, reflect damage to cell membranes, as well as changes in number and/or volume of lysosomes. Our results showed an increase in NR uptake by haemocytes from clams exposed to the highest NP concentration tested. As a first hypothesis, we suggest that changes in haemocyte membrane permeability occurred. Indeed, increased membrane permeability in haemocytes from NP-exposed clams presumably determined the higher NR assumption with respect to haemocytes from control clams. Although this needs to be verified, NP may act as a membraneactive molecule able to bind membrane proteins and phospholipids, similarly to what has been suggested for other lipophilic compounds. Indeed, in a recent study, severe haemocyte membrane injury, measured by a nigrosine dye test, was observed in haemocytes from Mytilus edulis exposed to tributyltin (TBT) and dibutyltin (DBT) (St-Jean et al. 2002). An increase in NR uptake was also demonstrated in haemocytes from cadmium-exposed mussels, M. edulis (Coles et al. 1995), whereas no significant differences in dye uptake were 


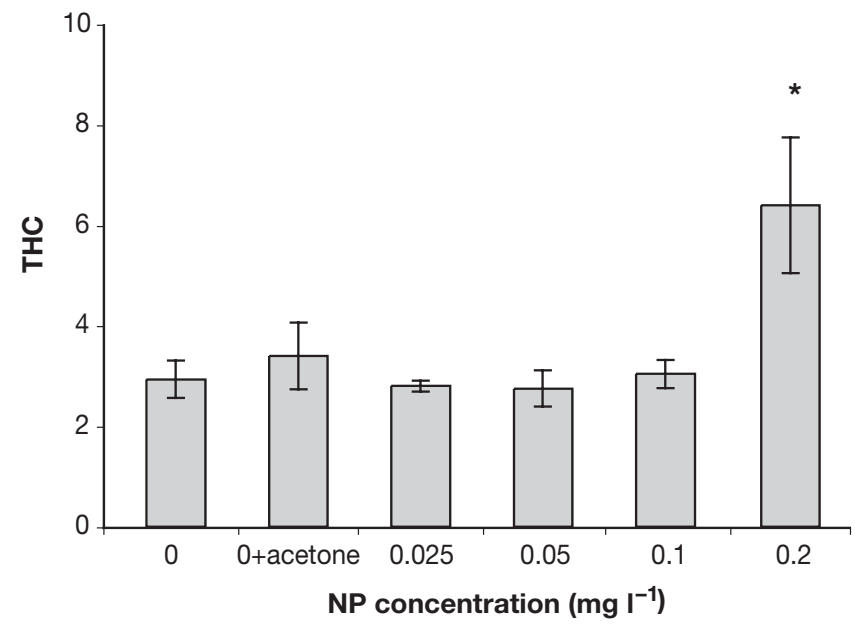

Fig. 7. Tapes philippinarum. Total haemocyte count (THC), expressed as number of haemocytes $\left(\times 10^{6}\right) \mathrm{ml}^{\text {haemolymph }}{ }^{-1}$, after exposure to NP. Asterisks: significant difference in comparison with controls. Values are means $\pm \mathrm{SD} ; \mathrm{n}=4 ;{ }^{*} \mathrm{p}<0.05$

recorded in haemocytes from copper-exposed mussels (Pipe et al. 1999). Haemocyte membrane destabilisation has also been revealed using other experimental methods. Significant increases in the uptake of ethidium homodimer-1 were recorded in haemocytes from Mya truncata after 2 wk exposure to PAH-contaminated sediments (Camus et al. 2003). As a second hypothesis, it cannot be excluded that, in haemocytes of exposed animals, NP caused an increase in the number and/or volume of lysosomes, which probably took up more NR than those of cells from control clams. This is in agreement with our previous findings. Indeed, increased NR uptake and enlarged lysosomes were observed in haemocytes from Tapes philippinarum exposed in vitro to TBT (Matozzo et al. 2002).

Haemocytes from NP-exposed clams showed a marked reduction in enzymatic activities. Anti-oxidant agents, such as SOD, catalase, glyoxalase, glutathione peroxidases and glutathione protect cells against ROSmediated oxidative damages (Di Giulio et al. 1989, Regoli \& Principato 1995). An important role in the anti-oxidant defence of aquatic invertebrates is mainly played by SOD and CAT (Winston 1991, Livingstone 2001). SOD, in particular, catalyses the dismutation of the superoxide radical $\left(\mathrm{O}_{2}^{-}\right)$to oxygen and hydrogen peroxide. It is well-known that increases in ROS levels may be due to exposure of animals to several contaminants, such as heavy metals, PAHs, polychlorobiphenyls and dioxins (Livingstone 2001, Geret et al. 2002, Orbea et al. 2002). Recently, it has been observed that NP may also enhance ROS production in human blood neutrophils (Okai et al. 2004). As a consequence, exposure to ROS-generating contaminants may increase or inhibit anti-oxidant enzyme activities in or- ganisms. Griveau et al. (1995) observed that ROS can inactivate anti-oxidant enzymes, such as glutathione peroxidase, glucose-6-phosphate dehydrogenase and SOD. In this study, the significant inhibition of SOD in NP-exposed clams may reflect the inability of cells to eliminate $\mathrm{O}_{2}{ }^{-}$, an oxygen metabolite responsible for oxidative stress in cells. NP exposure also decreased SOD activity in the digestive gland and gills of Tapes philippinarum (Matozzo et al. 2004). Decreased SOD activity was previously observed in haemocytes from T. philippinarum after $7 \mathrm{~d}$ exposure to copper (Matozzo et al. 2001), and in in vitro TBT-exposed haemocytes (Matozzo et al. 2002). We hypothesise that the inhibition of SOD observed in the present study is due to ROS-mediated oxidation of the enzyme $\mathrm{SH}$ groups. According to Roche \& Bogé (2000) and Okai et al. (2004), phenols increase ROS levels, which in turn cause inactivation of enzymes, determining oxidative damage.

In the immune system of bivalves, lysozyme is one of the most important bacteriolytic agents against several species of Gram-positive and Gram-negative bacteria (Cheng \& Rodrick 1974). Lysozyme is a lysosomal enzyme secreted by haemocytes in the haemolymph during phagocytosis, thus participating in the inactivation of invading pathogens. Reduced lysozyme activity, therefore, suggests immunosuppression, resulting in lowered resistance to bacterial challenge. In this study, significant inhibition of lysozyme activity was observed in haemocytes from $0.05 \mathrm{mg} \mathrm{l}^{-1} \mathrm{NP}$-exposed clams, confirming previous data concerning the capability of lipophilic contaminants to alter enzymatic activity in fish cells (Brüschweiler et al. 1996) and bivalve haemocytes (Cima et al. 1999, Matozzo et al. 2002). Although the mechanisms of action of the contaminant need to be more fully studied, we suggest that NP causes haemocyte degranulation, followed by a decrease in intracellular lysozyme activity, as well as an increase in extracellular enzyme activity. As in our previous observations in haemocytes of Tapes philippinarum, higher lysozyme levels than in the haemolymph were found (Matozzo et al. 2003b); in the present study, lysozyme activity was determined in haemocyte lysate. The lower intracellular lysozyme activity observed in NPexposed animals may, therefore, be due to increased enzyme secretion from haemocytes in the haemolymph. Interestingly, induction of haemocyte degranulation, followed by an increase in extracellular lysozyme activity, has recently been observed in haemocytes from Mytilus galloprovincialis exposed in vitro to $\mathrm{E}_{2}$ (Canesi et al. 2004). In this regard, it is important to highlight that NP can act by mimicking endogenous estrogens such as $\mathrm{E}_{2}$.

Apoptosis, or programmed cell death, is a physiological process by which useless cells are eliminated during normal cell turnover. Cells undergoing apop- 
tosis show peculiar morphological and biochemical features, such as shrinkage, membrane blebbing, chromatin condensation and DNA fragmentation, and formation of apoptotic bodies containing cellular organelles. In vivo, apoptotic bodies are generally recognised and phagocytised by either macrophages or active phagocytes. In the present study, both DNA fragmentation and cell shrinkage were observed in haemocytes from NP-exposed clams. Increased cellular apoptosis and shrinkage have also been found in spermatocytes and Sertoli cells from medaka Oryzias latipes exposed to NP, indicating testicular degeneration via testicular cell apoptosis (Weber et al. 2002). Similarly, apoptosis of cultured Sertoli cells was proposed as the major reason for the adverse effects of NP in rats (Wang et al. 2003). Apoptotic events have also been observed in haemocytes from the ascidian Botryllus schlosseri after in vitro exposure to TBT: haemocytes positive to the TUNEL reaction significantly increased, cell volume decreased, and plasma membranes acquired a blebbed appearance (Cima \& Ballarin 1999). Although the mechanisms by which apoptotic processes are regulated in bivalve molluscs are still unknown, DNA damage observed in haemocytes from NP-exposed clams was probably mediated by increases in cytosolic $\mathrm{Ca}^{2+}$ levels, which in turn can activate $\mathrm{Ca}^{2+}$-dependent DNA lytic enzymes, such as endonucleases. Apoptotic events mediated by a cytosolic $\mathrm{Ca}^{2+}$ increase (caused by inhibition of $\mathrm{Ca}^{2+}$ ATPase activity) have been proposed in previous studies (Cima \& Ballarin 1999, Hughes et al. 2000). In particular, among the compounds tested, NP has been shown to be the most potent inhibitor of the $\mathrm{Ca}^{2+}$ pump, and the resulting mobilisation of intracellular $\mathrm{Ca}^{2+}$ was associated with apoptotic cell death (Hughes et al. 2000). NP capability to disrupt $\mathrm{Ca}^{2+}$ homeostasis was also observed by Michelangeli et al. (1990).

NP also causes changes in both volume and morphology of haemocytes from Tapes philippinarum. According to Cima \& Ballarin (1999), haemocyte shrinkage is due to the release of fluid from cells after contaminant exposure. Indeed, higher haemocyte fractions showing smaller cell volume were found in NP-exposed clams with respect to controls, confirming our previous findings concerning haemocyte shrinkage (see the results of the apoptosis assay). In addition, the lost of amoeboid shape of haemocytes from T. philippinarum may be a consequence of ROS-mediated alterations in cytoskeleton organisation. GómezMendikute et al. (2002) found that oxidative stress mediated by increased levels of $\mathrm{ROS}\left(\mathrm{O}_{2}{ }^{-}\right.$, in particular) causes modifications in the cytoskeletal proteins of haemocytes from Mytilus galloprovincialis exposed in vitro to PAHs, provoking the disorganisation of the cytoskeleton. In this regard, it is important to empha- sise that a significant inhibition of SOD activity was recorded in haemocytes from NP-exposed clams, suggesting that cells were unable to eliminate $\mathrm{O}_{2}^{-}$. Moreover, as reported above, ROS have been shown to inactivate anti-oxidant enzymes, such as SOD (Griveau et al. 1995). It is, therefore, suggested that changes in the amoeboid shape of haemocytes from NP-exposed clams are a consequence of ROS-mediated oxidative stress.

Lastly, exposure to NP results in significant increases in the number of circulating haemocytes in Tapes philippinarum. Alterations in both the total numbers of circulating haemocyte and the relative proportion of cell types are generally considered a response to environmental stress (Pipe \& Coles 1995, Pipe et al. 1995, Matozzo et al. 2003b). Increases in the total numbers of circulating haemocytes may be due to either proliferation or movement of cells from tissues into the haemolymph, whereas decreases in numbers are considered to be a consequence of cell lysis (Pipe \& Coles 1995). In previous studies, exposure to contaminants, such as heavy metals, phenol and fluoranthene (Renwrantz 1990, Coles et al. 1994, Pipe et al. 1999), also caused increases in THC. According to Pipe et al. (1999), increased haemocyte numbers in NP-exposed clams are due to stimulation of haemocyte mobilisation from tissues to haemolymph during exposure; however, it cannot be excluded that the increased fraction of smaller circulating haemocytes (which may correspond to apoptotic bodies arising from NP-affected haemocytes) enhanced THC. Conversely, the increased fraction of larger haemocytes observed in clams exposed to the highest NP concentration tested also suggests the presence of haemocytes phagocytising apoptotic bodies.

\section{CONCLUSIONS}

Our results reveal that NP causes alterations in the functional responses of haemocytes from the clam Tapes philippinarum, indicating reduced immunocompetence in NP-exposed animals, even at NP concentrations similar to environmentally realistic levels (see Ying et al. 2002, for a review); however, a lack of data concerning the mechanisms of action of NP at the cellular level in bivalves makes a full evaluation of our results difficult. We hypothesise that NP acts negatively in the cytoplasm of bivalve haemocytes, affecting enzyme activities, whereas apoptotic events and changes in haemocyte morphology are probably caused by NP-mediated alterations in $\mathrm{Ca}^{2+}$ homeostasis and oxidative stress, respectively. For more information on the mechanisms of action of NP at the cellular level, as well as on increased susceptibility of 
NP-exposed clams to diseases, future research will be performed. The results already obtained also indicate that haemocytes represent a suitable model for evaluating NP toxicity in aquatic invertebrates. On the basis of the threshold concentration values, the most sensitive endpoints for NP are the SOD, lysozyme and apoptosis assays. Further studies in field conditions are, however, required to validate functional responses of haemocytes, such as those measured in clams exposed to NP in the laboratory.

\section{LITERATURE CITED}

Ahel M, McEvoy J, Giger W (1993) Bioaccumulation of the lipophilic metabolites of nonionic surfactants in freshwater organisms. Environ Pollut 79:243-248

Alvarez MR, Friedl FE (1992) Effects of a fungicide on in vitro hemocyte viability, phagocytosis and attachment in the American oyster, Crassostrea virginica. Aquaculture 107: $135-140$

Arukwe A, Förlin L, Goksøyr A (1997) Xenobiotic and steroid biotransformation enzymes in Atlantic salmon (Salmo salar) liver treated with an estrogenic compound, 4nonylphenol. Environ Toxicol Chem 16:2576-2583

Auffret M, Oubella R (1997) Hemocyte aggregation in the oyster Crassostrea gigas: in vitro measurement and experimental modulation by xenobiotics. Comp Biochem Physiol 118A:705-712

Ballarin L, Cima F, Sabbadin A (1994) Phagocytosis in the colonial ascidian Botryllus schlosseri. Dev Comp Immunol 18:467-481

Bechmann RK (1999) Effect of the endocrine disrupter nonylphenol on the marine copepod Tisbe battagliai. Sci Total Environ 233:33-46

Bennie DT (1999) Review of the environmental occurrence of alkylphenols and alkylphenol ethoxylates. Water Qual Res J Can 34:79-122

Blackburn MA, Waldock MJ (1995) Concentration of alkylphenols in rivers and estuaries in England and Wales. Water Res 29:1623-1629

Bradford MM (1976) A rapid and sensitive method for the quantification of microgram quantities of protein utilizing the principle of protein-dye binding. Anal Biochem 72: 248-254

Brunner PH, Capri S, Marcomini A, Giger W (1988) Occurrence and behaviour of linear alkylbenzenesulphonates, nonylphenol, nonylphenol mono and nonylphenol diethoxylates in sewage sludge treatment. Water Res 22: 1465-1472

Brüschweiler BJ, Würgler FE, Fent K (1996) Inhibition of cytochrome P4501A by organotins in fish hepatoma cells PLHC-1. Environ Toxicol Chem 15:728-735

Camus L, Birkely SR, Jones MB, Børseth JF and 5 others (2003) Biomarker responses and PAH uptake in Mya truncata following exposure to oil-contaminated sediment in an Arctic fjord (Svalbard). Sci Total Environ 308:221-234

Canesi L, Ciacci C, Betti M, Lorusso LC, Marchi B, Burattini S, Falcieri E, Gallo G (2004) Rapid effects of $17 \beta$-estradiol on cell signalling and function of Mytilus hemocytes. Gen Comp Endocrinol 136:58-71

Cheng TC (1988) In vivo effects of heavy metals on cellular defence mechanisms of Crassostrea virginica: phagocytic and endocytotic indices. J Invertebr Pathol 51:215-220

Cheng TC, Rodrick GE (1974) Identification and characteriza- tion of lysozyme from the hemolymph of the soft shelled clam, Mya arenaria. Biol Bull (Woods Hole) 147:311-320

Cheng TC, Sullivan JT (1984) Effects of heavy metals on phagocytosis by molluscan hemocytes. Mar Environ Res 14:305-315

Christensen LJ, Korsgaard B, Bjerregaard P (1999) The effect of 4-nonylphenol on the synthesis of vitellogenin in the flounder Platichthys flesus. Aquat Toxicol 46:211-219

Christiansen T, Korsgaard B, Jespersen $\AA$ (1998) Induction of vitellogenin synthesis by nonylphenol and $17 \beta$-estradiol and effects on the testicular structure in the eelpout Zoarces viviparus. Mar Environ Res 46:141-144

Cima F, Ballarin L (1999) TBT-induced apoptosis in tunicate haemocytes. Appl Organometal Chem 13:697-703

Cima F, Marin MG, Matozzo V, DaRos L, Ballarin L (1998) Immunotoxic effects of organotin compounds in Tapes philippinarum. Chemosphere 37:3035-3045

Cima F, Marin MG, Matozzo V, Da Ros L, Ballarin L (1999) Biomarkers for TBT immunotoxicity studies on the cultivated clam Tapes philippinarum (Adams and Reeve, 1850). Mar Pollut Bull 39:112-115

Coles JA, Farley SR, Pipe RK (1994) Effects of fluoranthene on the immunocompetence of the common marine mussel, Mytilus edulis. Aquat Toxicol 30:367-379

Coles JA, Farley SR, Pipe RK (1995) Alteration of the immune response of the common marine mussel Mytilus edulis resulting from exposure to cadmium. Dis Aquat Org 22: 59-65

Di Giulio RT, Washburn PC, Wenning RJ, Winston GW, Jewell CS (1989) Biochemical responses in aquatic animals: a review of determinants of oxidative stress. Environ Toxicol Chem 8:1103-1123

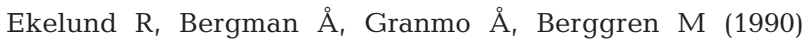
Bio-accumulation of 4-nonylphenol in marine animals. A re-evaluation. Environ Pollut 64:107-120

Ekelund R, Granmo Å, Magnusson K, Berggren M, Bergman $\AA$ (1993) Biodegradation of 4-nonylphenol in seawater and sediment. Environ Pollut 79:59-61

Fisher WS, Wishkovsky A, Chu FLE (1990) Effects of tributyltin on defense-related activities of oyster hemocytes. Arch Environ Contam Toxicol 19:354-360

Flohé L, Ötting F (1984) Superoxide dismutase assays. Meth Enzymol 105:93-104

Florence M, Carissan M, Hutchinson TH, Beaumont AR, Pipe RK (1997) Investigation on the effects of sodium pentachlorophenol on the immune system of marine mussels. Dev Comp Immunol 21:125

Flouriot G, Pakdel F, Ducouret B, Valotaire Y (1995) Influence of xenobiotics on rainbow trout liver estrogen receptor and vitellogenin gene expression. J Mol Endocrinol 15: 143-151

Geret F, Serafim A, Barreira L, Bebianno MJ (2002) Effect of cadmium on antioxidant enzyme activities and lipid peroxidation in the gills of the clam Ruditapes decussatus. Biomarkers 7:242-256

Gómez-Mendikute A, Exteberria A, Olabarrieta I, Cajaraville MP (2002) Oxygen radicals production and actin filament disruption in bivalve haemocytes treated with benzo(a) pyrene. Mar Environ Res 54:431-436

Granmo A, Ekelund R, Magnusson K, Berggren M (1989) Lethal and sublethal toxicity of 4-nonylphenol to the common mussel (Mytilus edulis L.). Environ Pollut 59: $115-127$

Griveau JF, Dumont E, Renard P, Callegari JP, Le Lannou D (1995) Reactive oxygen species, lipid peroxidation and enzymatic defense systems in human spermatozoa. J Reprod Fert 103:17-26 
Grundy MM, Moore MN, Howell SM, Ratcliffe NA (1996) Phagocytic reduction and effects on lysosomal membranes by polycyclic aromatic hydrocarbons, in haemocytes of Mytilus edulis. Aquat Toxicol 34:273-290

Hansen FT, Forbes VE, Forbes TL (1999) Effects of 4-nnonylphenol on life-history traits and population dynamics of a polychaete. Ecol Appl 9:482-495

Hughes PJ, McLellan H, Lowes DA, Zafar Kahn S and 6 others (2000) Estrogenic alkylphenols induce cell death by inhibiting testis endoplasmic reticulum $\mathrm{Ca}^{2+}$ pumps. Biochem Biophys Res Commun 277:568-574

Kvestak R, Ahel M (1994) Occurrence of toxic metabolites from nonionic surfactants in the Krka river estuary. Ecotox Environ Safe 28:25-34

Lee HB (1999) Review of analytical methods for the determination on nonylphenol and related compounds in environmental samples. Water Qual Res J Can 34:3-35

Livingstone DR (2001) Contaminant-stimulated reactive oxygen species production and oxidative damage in aquatic organisms. Mar Pollut Bull 42:656-666

Madigou T, Le Goff P, Salbert G, Cravedi JP, Segner H, Pakdel F, Valotaire Y (2001) Effects of nonylphenol on estrogen receptor conformation, transcriptional activity and sexual reversion in rainbow trout (Oncorhynchus mykiss). Aquat Toxicol 53:173-186

Maguire RJ (1999) Review of the persistence on nonylphenol and nonylphenol ethoxylates in aquatic environments. Water Qual Res J Can 34:37-78

Marcomini A, Pojana G, Sfriso A, Alonso Quiroga JM (2000) Behaviour of anionic surfactants and their persistent metabolites in the Venice lagoon, Italy. Environ Toxicol Chem 19:2000-2007

Matozzo V, Ballarin L, Pampanin DM, Marin MG (2001) Effects of copper and cadmium exposure on functional responses of hemocytes in the clam, Tapes philippinarum. Arch Environ Contam Toxicol 41:163-170

Matozzo V, Ballarin L, Marin MG (2002) In vitro effects of tributyltin on functional responses of haemocytes in the clam Tapes philippinarum. Appl Organomet Chem 16: 169-174

Matozzo V, Deppieri M, Moschino V, Marin MG (2003a) Evaluation of 4-nonylphenol toxicity in the clam Tapes philippinarum. Environ Res 91:179-185

Matozzo V, Da Ros L, Ballarin L, Meneghetti F, Marin MG (2003b) Functional responses of haemocytes in the clam Tapes philippinarum from the Lagoon of Venice: fishing impact and seasonal variations. Can J Fish Aquat Sci 60: 949-958

Matozzo V, Ballarin L, Marin MG (2004) Exposure of the clam Tapes philippinarum to 4-nonylphenol: changes in antioxidant enzyme activities and re-burrowing capability. Mar Pollut Bull 48:563-571

Michelangeli F, Orlowski S, Champeil P, East JM, Lee AG (1990) Mechanism of inhibition of the $\left(\mathrm{Ca}^{2+}-\mathrm{Mg}^{2+}\right)$-ATPase by nonylphenol. Biochemistry 29:3091-3101

Okai Y, Sato EF, Higashi-Okai K, Inoue M (2004) Enhancing effect of the endocrine disruptor para-nonylphenol on the generation of reactive oxygen species in human blood neutrophils. Environ Health Perspect 112:553-556

Orbea A, Ortiz-Zarragoitia M, Cajaraville MP (2002) Interactive effects of benzo(a)pyrene and cadmium and effects of di(2-ethylhexyl) phthalate on antioxidant and peroxisomal enzymes and peroxisomal volume density in the digestive

Editorial responsibility: Otto Kinne (Editor-in-Chief), Oldendorf/Luhe, Germany gland of mussel Mytilus galloprovincialis Lmk. Biomarkers 7:33-48

Pipe RK, Coles JA (1995) Environmental contaminants influencing immune function in marine bivalve molluscs. Fish Shellfish Immunol 5:581-595

Pipe RK, Coles JA, Thomas ME, Fossato VU, Pulsford AL (1995) Evidence for environmentally derived immunomodulation in mussels from the Venice Lagoon. Aquat Toxicol 32:59-73

Pipe RK, Coles JA, Carissan FMM, Ramanathan K (1999) Copper induced immunomodulation in the marine mussel Mytilus edulis. Aquat Toxicol 46:43-54

Regoli F, Principato G (1995) Glutathione, glutathionedependent and antioxidant enzymes in mussel, Mytilus galloprovincialis, exposed to metals under field and laboratory conditions: implications for the use of biochemical biomarkers. Aquat Toxicol 31:143-164

Renwrantz L (1990) Internal defence system of Mytilus edulis. In: Stefano GB (ed) Studies in neuroscience: neurobiology of Mytilus edulis. Manchester University Press, Manchester, p 256-275

Roche H, Bogé G (2000) In vivo effects of phenolic compounds on blood parameters of a marine fish Dicentrarchus labrax. Comp Biochem Physiol 125C:345-353

Sami S, Faisal M, Huggett RJ (1992) Alterations in cytometric characteristics of hemocytes from the American oyster Crassostrea virginica exposed to a polycyclic aromatic hydrocarbon $(\mathrm{PAH})$ contaminated environment. Mar Biol 113:247-252

Santarem MM, Robledo JAF, Figueras A (1994) Seasonal changes in hemocytes and serum defense factors in the blue mussel Mytilus galloprovincialis. Dis Aquat Org 18: $217-222$

Sauvé S, Brousseau P, Pellerin J, Morin Y, Senécal L, Goudreau P, Fournier M (2002) Phagocytic activity of marine and freshwater bivalves: in vitro exposure of hemocytes to metals ( $\mathrm{Ag}, \mathrm{Cd}, \mathrm{Hg}$ and $\mathrm{Zn}$ ). Aquat Toxicol 58:189-200

Servos MR (1999) Review of the aquatic toxicity, estrogenic responses and bioaccumulation of alkylphenols and alkylphenol polyethoxylates. Water Qual Res J Can 34: 123-177

St-Jean SD, Pelletier E, Courtenay SC (2002) Hemocyte functions and bacterial clearance affected in vivo by TBT and DBT in the blue mussel Mytilus edulis. Mar Ecol Prog Ser 236:163-178

Viarengo A, Canesi L, Moore MN, Orunesu M (1994) Effects of $\mathrm{Hg}^{2+}$ and $\mathrm{Cu}^{2+}$ on the cytosolic $\mathrm{Ca}^{2+}$ level in molluscan blood cells evaluated by confocal microscopy and spectrofluorimetry. Mar Biol 119:557-564

Wang X, Han X, Hou Y, Yao G, Wang Y (2003) Effect of nonylphenol on apoptosis of Sertoli cells in vitro. Bull Environ Contam Toxicol 70:898-904

Weber LP, Kiparissis Y, Hwang GS, Niimi AJ, Janz DM, Metcalfe CD (2002) Increased cellular apoptosis after chronic aqueous exposure to nonylphenol and quercetin in adult medaka (Oryzias latipes). Comp Biochem Physiol 131C: $51-59$

Winston GW (1991) Oxidants and antioxidants in aquatic animals. Comp Biochem Physiol 100C:173-176

Ying GG, Williams B, Kookana R (2002) Environmental fate of alkylphenols and alkylphenol ethoxylates - a review. Environ Int 28:215-226

Submitted: April 20, 2004; Accepted: September 16, 2004 Proofs received from author: December 21, 2004 